\title{
О компрессивном словообразовании в специальной лексике «банковского дела»
}

\author{
НИНА МАГОЧИ \\ MÁGOCsi Nyina, ELTE Orosz Nyelvi és Irodalmi Tanszék, H-1088 Budapest, Múzeum krt. 4/D. \\ E-mail: magocsi.nyina@gmail.com
}

(Received: 4 August 2016; accepted: 11 October 2016)

\begin{abstract}
This paper presents examples of special-purpose banking language items which illustrate word formation processes in present-day Russian used in the sphere of banking in order to compress meaning, i.e. univerbation as well as abbreviation. As a rule, these particular phenomena are considered one of the manifestations of the principle of linguistic economy. The orientation towards linguistic economy provides a stimulus for multiplying the number of new lexical items in banking language, which can be related to technical terms and professional slang. The productivity of word formation processes used in order to compress meaning can also be linked to the needs of adjusting written and oral communication to the world standards in the sphere of Russian banking.

Keywords: special vocabulary, banking terminology, Russian word formation, univerbation, abbreviation, technical terms, professional slang
\end{abstract}

В современной русской специальной банковской лексике отражается ряд процессов, которые характеризуют современный русский язык в целом: 1) активизация определенных звеньев словообразовательной системы языка для наименования новых явлений и процессов, и, как результат, появление огромного количества языковых неологизмов; 2) перемещение в центральные сферы коммуникации явлений периферийных, сниженной лексики разного рода; в нашем случае это - профессионализмы и профессиональный сленг (ЗЕМСКАЯ 1996: 90-92).

Настоящая статья фокусируется на рассмотрении таких «компрессирующих смысл» словообразовательных процессов в сегодняшнем русском языке банковского дела, как универбация и аббревиация.

Продуктивность данных способов компрессивного словопроизводства в банковской лексике усматривается нами в необходимости для специалистов этой сферы быстро и точно обозначать проблемы, емко, но кратко формулировать задачи, задавать вопросы и выяснять ситуацию. «Образование универбатов - одно из проявлений закона экономии языка... Экономия выражается в создании удобных способов передачи информации, не препятствующих пониманию сообщения. Универбаты как сокращенные единицы, однозначно трактуемые коммуникантами в данной речевой ситуации, несомненно, экономят время и произносительные усилия говорящего» (ДозоровА 2014: 1631). 
Тенденция к языковой экономии дает стимул к увеличению числа новых единиц языка банковской специальности, относимых к профессионализмам и профессиональному сленгу. При выделении этой группы специальной лексики, мы опирались на предлагаемый российским лингвистом 3. И. Комаровой «стилистико-лексический» подход, согласно которому специальная лексика разделяется на три основных разряда: 1) термины, 2) профессионализмы и 3) сленгизмы.

1) Термины - это официальные, общепринятые в кругу специалистов стилистически нейтральные слова.

2) Профессионализмы (или разговорные термины) - это неофициальные, но общепринятые специалистами данной отрасли общеупотребительные специальные слова.

3) Сленгизмы (или профессиональные арготизмы) - это необщеупотребительные, фамильярно-разговорные специальные слова (КомАРовА 1979).

\section{Универбация}

Универбация (от лат. ипum verbum 'одно слово') - способ образования слова на основе словосочетания, при котором в производное слово входит основа лишь одного из членов словосочетания, то есть по форме производное соотносительно с одним словом, а по смыслу - с целым словосочетанием. В лингвистической литературе этот способ образования имеет несколько названий: включение, стяжение, семантическая конденсация, эллипсис и эллиптизация, свертывание наименований или, чаще всего, универбация (см. КосовА-Сунь 2015: 69-70). Вопрос об универбации как средстве компрессии неоднословных номинаций является одной из актуальных тем дериватологии современных славянских языков (ДозоровА 2014: 1631).

В результате универбации образуются краткие неофициальные наименования для понятий, обозначаемых в официальной речи обычно словосочетательной конструкцией. Универбаты - принадлежность разговорного языка, но с конца XX века они начали широко употребляться в лексике печатных изданий, а также фиксироваться в толковых словарях и различных словарях специальной лексики.

Наряду с номинативной функцией данного вида словообразования Е. А. Земская выделяет его конструктивную, компрессивную, экспрессивную и стилистическую функцию (ЗЕмскАЯ 1992: 8-9). Именно эмоционально-экспрессивными свойствами универбатов объясняется тот факт, что наибольшее число универбатов возникает в разговорной и разговорно-профессиональной речи, в речи различных социальных групп, объединяемых общими интересами.

Мы остановимся на особенностях образования банковских универбатов и их примерах, собранных нами из российских периодических и интернетизданий «Коммерсантъ», «Ведомости», «Финансовые известия», «Эксперт», 
«Вести-Финансы», «Аргументы и факты», экономических электронных словарей, справочников данных Интернета, Национального корпуса русского языка, а также в результате анализа финансовых документов: отчетов, протоколов заседаний, выдержек из рассылок и электронных писем работников банковской сферы.

Универбаты чаще всего образуются на основе стяжения словосочетаний:

1) «прилагательное + существительное»: аналитика - аналитический учет; межфилиалка - межфилиальные расчеты; мемрик (или мылмик) мемориальный ордер; незавершенка - незавершенные расчеты; кредитка кредитная карта; платежка - платежное поручение; приходник - приходный кассовый ордер; расходник - расходный кассовый ордер; физик - физическое лицо; юрик - юридическое лицо; наличность (или наличка) - наличные деньги; безналичка - безналичный расчет;

2) «существительное + существительное в родительном падеже: обменник - пункт обмена валюты;

3) «существительное + предлог + существительное в косвенном падеже»: распоряга - распоряжение о проведении операции;

4) а также их модификации: внебаланс - операции по внебалансовому учету; кредитники (кредитчики) - сотрудники отделов кредитования; отчетники - сотрудники отдела отчетности; продажники - сотрудники отдела продаж; ЦБиники - сотрудники Центрального Банка Российской Федерации; рисковики - сотрудники отдела рисков.

Большинство слов-универбатов образованы при помощи суффикса $-\kappa(a)$ : безналичка, незавершенка. Данный суффикс относится к числу «общепредметных и предназначен для выражения самой широкой категориальной (частеречной) предметной семантики» (КосовА-Сунь 2015: 69).

Для наименования специалистов узких сфер деятельности широко употребляются суффиксы -ик; -ник; -иник: отчетник, ЦБиник. Последний пример является образованием от двучленной аббревиатуры ЦБ (Центральный Банк). Реже образуются универбаты с суффиксом -г(a): распоряга, или же -щинн(a): банкировщина. Два последних суффикса имеют пренебрежительную эмоционально-стилистическую окраску.

Универбаты также образуются бессуффиксальным способом путем свертывания объясняющего специальное понятие словосочетания по типу сложносокращенных аббревиатур: внутрибанк - внутрибанковские операции; межбанк - межбанковский кредит.

При универбации часто наблюдается усечение мотивирующей основы: голова - головная организация банка; поз - позиция (платежная и т. п.); cuнтетика - синтетический учет (учет по синтетическим, т. е. обобщенным счетам бухгалтерского учета); допник - дополнительное соглашение к договору; казначеи - сотрудники отдела Казначейства; пластик - пластиковая карта, а также омоним этого универбата - сотрудники отдела пластиковых карт.

Стоит отметить частый переход рассмотренных лексических единиц профессиональной речи в язык узуального общения. Такие слова и выражения, 
как наличка, обменник, кредитка, безналичка или платежка сейчас широко употребляются и в повседневной речи.

Стремление назвать единым словом специальное понятие, обозначаемое описательно, т. е. с помощью составного наименования, стимулирует процессы словообразования специальных лексических единиц не только в разряде профессионализмов. Регулярное изменение банковского законодательства, постоянное внедрение новых банковских услуг, непрерывный процесс записи произведенных операций, стремительное развитие банковских технологий, заимствование терминов из иностранных языков также обусловливают продуктивность «экономных» способов словообразования. Широкое распространение в банковской лексике, наряду с универбацией, получает и другой «компрессивный» способ словообразования - аббревиация.

\section{Аббревиация}

Наряду с универбатами в русской специальной банковской лексике широко образуется такой тип сокращений, как аббревиатура - слово, образованное сокращением слов или словосочетаний и читаемое по алфавитному названию начальных букв или по начальным звукам слов, входящих в него.

В русском языке аббревиатуры начали образовываться еще до октябрьской революции, например, ПТА (Петербургское телеграфное агентство). Но активное образование аббревиатур началось уже после революции, и в современном русском языке аббревиация является одним из наиболее распространенных словообразовательных средств. А причина та же - сократить длинные, многословные и часто употребляемые составные наименования.

Аббревиатуры делятся на сложносокращенные слова и инициальные аббревиатуры.

Сложносокращенное слово - это слово, составленное из сокращенных начальных элементов (морфем) словосочетания. Из банковской лексики в качестве примеров можно привести названия банков: Сбербанк, ВнешТоргБанк, а также профессионализмы, которые будут рассмотрены ниже: внутрибанк, межбанк, опердень, теховер.

Внутри инициального типа аббревиатур выделяются два подтипа:

1) звуковой: образуется путем сочетания начальных звуков всех компонентов, входящих в состав соответствующего полного наименования: $B У 3$, ГАИ, ЗАГС, НИИ, СМИ и т. П. (ЛоПАТин 1978: 72). В банковской лексике нами обнаружен лишь один пример этого подтипа аббревиации: МОП - минимальный обязательный платеж как часть полной задолженности по кредиту.

2) буквенный: образуется путем сочетания начальных букв всех компонентов, входящих в состав соответствующего полного наименования: $P К O$ (представляет собой явление омонимии): в зависимости от контекста либо расходный кассовый ордер, либо - расчетно-кассовое обслуживание; РКЦ расчетно-кассовый центр; МБК - межбанковский кредит; ГРКЦ - головной 
расчетно-кассовый центр; НКО - некоммерческая организация; ОРЦБ - организованный рынок ценных бумаг; ПРС - Подразделение расчетной сети (Банка России); ДБО - дистанционное банковское обслуживание; ПВН пункт выдачи наличных с использованием банковских карт; $Т Б С-$ текущий банковский счет; НСПК - Национальная система платежных карт.

В этот наиболее представленный подтип аббревиации входят также названия банков и обозначение их структурно-иерархаичного деления: ЦБРФЦентральный Банк Российской Федерации (Центробанк); ТУСБ - Территориальные управления Сбербанка; $А К Б$ - Филиал акционерного коммерческого банка; ФКОБ - Филиал кооперативного банка; ФЧКБ - Филиал частного коммерческого банка; ЧКБ - Частный коммерческий банк; ВТБ - Внешний Торговый Банк (ВнешТоргБанк).

Т. А. Тулина выделяет особый вид инициального сокращения, называя его выборочно-инициальным, так как букву получает не каждое слагаемое, а лишь некоторые, семантически наиболее весомые (ТулинА 1974: 85). Приведем собственные примеры из банковской лексики: $Р В П C-$ резервы на возможные потери по ссудам; $Ф О Р$ - обязательные резервы, перечисляемые в Центральный банк РФ; БЭСП- системы банковских электронных срочных платежей; H6 - один из обязательных нормативов банков, ограничивающий выдачу денег в «одни руки» (сумму вложений в активы одного лица или группы связанных лиц); OHК - организация, не являющаяся кредитной; $Н Д К О-$ $H K O$, осуществляющая депозитно-кредитные операции.

В сфере двучленных сочетаний мы обнаружили следующие аббревиатуры: ЦБ - Центральный банк (Центробанк), $C D$ - Сберегательный банк России (Сбербанк); ВБ - Всемирный банк; $К Б$ - коммерческий банк; $Ф Б-$ фи-

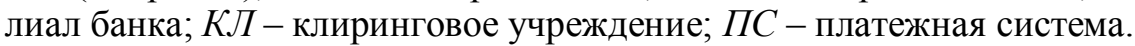

В современном банковско-финансовом языке для специальных целей все чаще появляются сокращения и аббревиатуры иностранных словосочетаний в неизменной форме, часто в качестве иноязычного вкрапления: $P O S$ электронное устройство, с помощью которого держатель платежной карты имеет возможность оплатить товары; FIDR - процентная ставка по срочным депозитам физических лиц в валюте, тождественной валюте кредита; ATM банкомат; FOREX - внебиржевой валютный рынок; IBAN - номер счета клиента в европейском банке, необходимый реквизит для перечисления денег из России в Европу; SWIFT - международная телекоммуникационная система для обмена сообщениями между финансовыми организациями.

Стоит отдельно отметить внедрившиеся в практику переводы иноязычных аббревиатур: ср. ПИН-код - персональный идентификационный номер (personal identification number); БИК - банковские идентификационные коды (bank identifier code); РЕПО - сделка, которая состоит из двух стадий: продажи и дальнейшего выкупа ценных бумаг через определенный срок и по заранее оговоренным условиям и ценам (repurchase agreement); $M B \Phi-$ Международный валютный фонд (International Monetary Fund); ЕЦБ - Европейский центральный банк (European Central Bank). 
Кроме приведенных выше примеров универбации и аббревиации в банковской лексике нами обнаружены и другие интересные примеры «компрессии смысла». Так, например, банковские профессионализмы образуются не мотивированными словосочетанием единицами, в которых сжато передается содержание обозначаемых ими явлений или процессов: тело кредита - сумма основного долга по кредиту без учета процентов и иных составляющих долга; хотелки - пожелания по автоматизации или списки потребностей для работы; наџпокрытие - рублевый эквивалент любой валюты; невыясненные суммы, не подлежащие зачислению на счета из-за ошибок в расчетных документах; выписка - справка о состоянии счета и операций по нему за какойлибо период.

Среди лексических единиц банковского профессионального сленга можно выделить и свертывающие описательную конструкцию сокращения с заимствованным мотивирующим словом: свифтовка - распечатанное свифтсообщение; теховер - технический овердрафт; опердень - операционный день банка. Прослеживается графическая адаптация в новообразованиях от некоторых аббревиатур. В качестве примера приведем уже упомянутый профессионализм и его официальное описательное значение, которое можно причислить к гибридным составным терминам: свифтовка-распечатанное свифт-сообщение. Мотивирующей основой этих новообразований служит иноязычная аббревиатура: SWIFT - Society for Worldwide Interbank Financial Telecommunications.

Стоит отметить частое употребление в профессиональном сленге графически адаптированных заимствованных слов с усеченной основой: инфа информация; овер - овердрафт.

Заслуживают внимания единицы профессионального сленга, построенные по модели «глагол + существительное в винительном падеже или косвенном падеже»: пробить по базе - проверить клиента через службу безопасности, делать ручками - проводить какие-либо операции вручную, не программным способом; идти в поля - искать клиентов, ездить на переговоры с потенциальными клиентами.

Наше внимание привлек и заголовок статьи в газете «Коммерсантъ» от 12 декабря 2013 г. «Возьмибанкировщина», в которой критикуется система начисления бонусов банкирам. Это новообразование можно отнести к профессионализмам и рассматривать как средство экспрессии, стилистической маркировки речи, окрашенной пейоративным, уничижительным оттенком.

Подытоживая рассмотренные в статье процессы, происходящие современном банковском языке для специальных целей, следует отметить значительное влияние экстралингвистических факторов, связанных, с одной стороны, с изменением характера профессионального общения - расширение отношений банка с общественностью, и как следствие, персонификация и диалогизация специальной банковской коммуникации, а с другой - необходимость адаптации русской банковской письменной и устной коммуникации к мировым стандартам. 


\section{Литература}

ДозоровА 2014 = ДозоровА Д. В. Динамика развития тематических групп универбатов в русском языке. Фундаментальные исследования 2014/11: 1631-1635.

ЗЕМСКАЯ 1992 = ЗЕМСКАЯ Е. А. Словообразование как деятельность. Москва, 1992.

ЗЕМСКАЯ 1996 = ЗЕМСКАЯ Е. А. АктивНЫе процессы современного словопроизводства. В кн.: ЗЕмская Е. А. (ред.) РУсский язык кониза ХХ столетия (1985-1995). Москва, 1996. 90-140.

КомАРОВА $1979=$ КомАРОВА З. И. О сущности термина. В кн.: Термин и слово. Горький, 1979. 3-13.

КосовА-Сунь 2015 = КосовА В. А., Сунь Мяо: Функциональная семантика универбов в русских социолектах. Филология и культура. Philology and Culture 2015/3: 67-74.

ЛоПАТин 1978 = ЛоПАТин В. В. Суффиксальная универбация и смежные явления в сфере образования новых слов. В кн.: Новые слова и словари новых слов. Ленинград, 1978. 72-80.

Сунь 2014 = Сунь Мяо: Универбация в русском жаргонном компрессивном словообразовании. Современные проблемы науки и образования 2014/3. http://www. science-education.ru/ru/article/view?id=13629.

ТулинА 1974 = ТулинА Т. А. Способы словообразования слов на базе словосочетаний. Русский язык в школе 1974/4: 84-87. 